\title{
Peran Peradilan Islam dalam Penegakan Hukum Islam di Kesultanan Buton
}

\author{
Asni
}

\begin{abstract}
The Role of Islamic Courts in the Enforcement of Islamic Law in the Past of Buton's Sulthanante. This article tries to reveal the existence of the Islamic Courts in the Sultanate of Buton to measure the extent of its role in the enforcement of Islamic Law in the past. History explains that when Islam entered the territory of Southeast Sulawesi, the kingdom of Buton changed its status to Buton Sultanate and applied Islamic law throughout the empire. Using historical approach, the researcher succeeded in revealing the fact that in the area of the past Sultanate of Buton, once stood two institutions of Islamic Court named Syarana Adati and Syarana Hukumu or Syarana Agama. The authority of Syarana Adati was to deal with criminal cases where as Syarana Hukumu or Syarana Agama took care of certain civil cases such as marriage, divorce and inheritance. Despite the separation of authority, the two institutions can be categorized as Islamic Courts because the legal system used as a backdrop was Islamic Law. The study also finds out that the two institutions play a significant role in the upholding of Islamic law in the past as they were supported by the kingdom, and a strong legal culture both among law enforcers and in the community.
\end{abstract}

Keywords: Islamic court in Buton sultanate, history of the Buton sultanate

\begin{abstract}
Abstrak: Peran Peradilan Islam dalam Penegakan Hukum Islam di Kesultanan Buton. Artikel ini mencoba menguak eksistensi Peradilan Islam di Kesultanan Buton sekaligus menakar sejauh mana peranannya dalam penegakan Hukum Islam di masa lampau.. Sejarah menerangkan bahwa ketika agama Islam masuk ke wilayah Sulawesi Tenggara kerajaan Buton merubah statusnya menjadi Kesultanan Buton dan menerapkan Hukum Islam di seluruh wilayah kesultanan. Melalui pendekatan pendekatan sejarah, studi ini berhasil mengungkap fakta bahwa di masa lampau, di wilayah Kesultanan Buton, pernah berdiri dua lembaga Peradilan Islam yang bernama Syarana Adati dan Syarana Hukumu atau Syarana Agama. Wewenang Syarana Adati adalah menangani perkara pidana sedangkan Syarana Hukumu atau Syarana Agama mengurusi perkara perdata tertentu seperti perkawinan, perceraian dan kewarisan. Meski terjadi pemisahan kewenangan, kedua lembaga tersebut dapat dikategorikan sebagai Peradilan Islam karena sistem hukum yang dijadikan sandaran adalah Hukum Islam. Penelitian ini juga menemukan bahwa kedua lembaga tersebut berperan secara signifikan dalam penegakan hukum Islam di masa lampau karena ditopang oleh kerajaan, dan kultur hukum yang kuat baik di kalangan penegak hukum maupun di tengah masyarakat.
\end{abstract}

Kata Kunci: Peradilan Islam di kesultanan Buton, sejarah kesultanan Buton

Institut Agama Islam Negeri Kendari

Jl. Sultan Qaimuddin No. 17 Kendari

E-mail: asni.azrai@yahoo.co.id 


\section{Pendahuluan}

Penegakan hukum dan keadilan merupakan bagian yang sangat penting dalam sebuah masyarakat. Penegakan hukum dan keadilan direpresentasikan oleh negara melalui otoritas sebuah lembaga resmi yang disebut peradilan. Melalui lembaga peradilanlah, penegakan hukum dan keadilan dalam masyarakat dapat diwujudkan. Islam memberikan perhatian khsusus terhadap institusi peradilan karena kemaslahatan sosial sebagai tujuan hukum Islam hanya dapat diwujudkan jika hukum dan keadilan ditegakkan. Pentingnya institusi ini dalam Islam dapat diamati dalam beberapa ayat Alquran maupun hadis-hadis yang berkaitan dengan peradilan, antara lain perintah bagi hakim untuk berijtihad, etika hakim dan lain-lain. Kesemua hal tersebut mempertegas pentingnya peradilan dalam Islam.

Peradilan menjadi bagian tak terpisahkan dari sejarah perkembangan hukum Islam. Hal ini dapat dilihat dari eksistensi peradilan yang telah dimulai dari masa Rasulullah Saw lalu diteruskan di masa-masa sahabat dan terus berlanjut ke masa-masa setelahnya hingga masa sekarang. ${ }^{1}$ Hal ini mengindikasikan bahwa eksistensi peradilan merupakan bagian penting dalam pelaksanaan hukum Islam di masyarakat muslim, baik di masa lalu maupun di masa kini pada berbagai belahan dunia, termasuk di Indonesia.

Eksistensi peradilan Islam di Indonesia yang saat ini dikenal dengan Peradilan Agama maupun Mahkamah Syariah, merupakan hasil dari sebuah perjalanan sejarah yang cukup panjang. Cikal bakal Peradilan Agama muncul beriringan dengan masuknya Islam di bumi nusantara. Kelembagaan Peradilan Agama telah melewati berbagai fase sejarah, mulai dari periode tahkim, tauliyah dan ablul halli wa al-aqdi, periode kesultanan, periode penjajahan, masa kemerdekaan hingga masa reformasi sekarang ini. Pasang surut keberadaan Peradilan Agama dalam sejarahnya

\footnotetext{
${ }^{1}$ Meski para ahli hukum Islam berbeda pendapat tentang kapan dimulainya peradilan dalam Islam, dalam beberapa literatur disebutkan bahwa dimulainya peradilan dalam Islam adalah sejak Nabi Muhammad diangkat menjadi rasul, tepatnya ketika terbentuknya sistem pemerintahan di kota Madinah. Sejak itu, banyak kegiatan peradilan dilaksanakan nabi, terutama menyangkut penegakan hukum kepada seluruh warga masyarakat.
} 
tampaknya sangat terkait dengan perkembangan politik dari masa ke masa.

Sejarah Peradilan Agama di Indonesia, tidak bisa dilepaskan dari sejarah Kesultanan Islam masa lalu yang terdapat di beberapa wilayah nusantara. Khusus di Sulawesi Tenggara, terdapat beberapa kerajaan yang cukup besar pernah berkuasa dan berpengaruh terhadap Islamisasi di wilayah Sulawesi Tenggara. Kerajaan tersebut antara lain adalah Kerajaan Buton. Kerajaan Buton, setelah Islamisasi sekitar tahun 948 H/1540 M, ${ }^{2}$ secara resmi berganti menjadi Kesultanan Buton, merupakan salah satu kesultanan di bumi nusantara yang cukup fenomenal antara lain karena masa kekuasaannya yang cukup lama, yakni berlangsung hingga tahun 1960 dan dipimpin sebanyak 35 raja atau sultan. Selain itu, Kesultanan Buton juga cukup banyak meninggalkan jejak sejarah baik dalam bentuk situs-situs bersejarah maupun catatan sejarah seperti naskah-naskah kuno yang masih bisa disaksikan sampai hari ini.

Sebagai Kesultanan Islam yang cukup fenomenal, tentunya peran Kesultanan Buton dalam mensosialisasikan dan melaksanakan hukum Islam cukup signifikan. Namun suatu hal yang menjadi pertanyaan, bagaimana sistem pelembagaan hukum Islam di Kesultanan Buton ketika itu? Apakah telah terdapat institusi dan legislasi yang mengatur pelaksanaan peradilan dan bagaimana model pelembagaan maupun aparatur peradilan Islam ketika itu? Apakah sistem peradilan di Kesultanan Buton ketika itu masuk dalam kategori peradilan Islam sebagaimana dikembangkan dari masa Rasulullah dan setelahnya? Serta apakah lembaga tersebut memiliki peran yang cukup signifikan dalam penegakan hukum Islam di Kesultanan Buton ketika itu?

Berdasarkan latar belakang di atas, permasalahan pokok dalam tulisan ini adalah bagaimana eksistensi peradilan Islam dalam penegakan hukum Islam di Kesultanan Buton? Permasalahan tersebut dikembangkan dalam sub-sub masalah adalah bagaimana gambaran penegakan hukum Islam di Kesultanan Buton? Bagaimana pengorganisasian peradilan di Kesultanan 
Buton? Bagaimana peran peradilan Islam dalam penegakan hukum Islam di Kesultanan Buton?

Tulisan ini diharapkan bisa menjadi media untuk mengetahui secara mendalam penegakan hukum Islam di Kesultanan Buton melalui lembaga peradilan sekaligus untuk menganalisis konsistensi lembaga tersebut dengan sistem peradilan Islam yang dikembangkan dalam sejarah Islam awal. Secara rinci, tulisan ini memiliki beberapa bertujuan. Pertama, untuk mengetahui gambaran penegakan hukum Islam di Kesultanan Buton. Kedua, menelusuri pengorganisasian peradilan di Kesultanan Buton. Ketiga, menggali dan mengetahui peran institusi hukum Islam pada masa Kesultanan Buton dalam mewujudkan penegakan hukum di Kesultanan Buton

Informasi mengenai hal ini cukup penting dalam upaya memperkaya literatur keilmuan hukum Islam khususnya dari sisi historitas Peradilan Agama. Di samping itu, tulisan ini nantinya diharapkan dapat memberi informasi berharga bagi praktisi-praktisi peradilan dalam rangka pemantapan pelaksanaan dan penguatan kelembagaan peradilan, dalam rangka penegakan hukum dewasa ini.

\section{Penegakan Hukum}

Institusi hukum dalam penegakan hukum dapat dipahami berdasarkan pada teori Sistem Hukum yang digagas oleh Lawrence M. Friedman, sebagaimana dikutip oleh Satjipto Rahardjo, meliputi 3 unsur penting yakni struktur hukum, substansi hukum dan budaya hukum ${ }^{3}$

Senada dengan itu, namun dielaborasi lebih rinci, penegakan hukum menurut Soerjono Soekanto meliputi 5 (lima) aspek pokok, meliputi faktor hukumnya, faktor penegak hukumnya, faktor sarana atau fasilitas, faktor masyarakat dan faktor kebudayaan. ${ }^{4}$ Struktur mencakup institusiinstitusi dan aparat penegak hukum. Adapun struktur dalam sistem hukum Indonesia adalah termasuk struktur institusi lembaga peradilan di samping

${ }^{3}$ Satjipto Rahardjo, Penegakan Hukum: Suatu Tinjauan Sosiologis (Yogyakarta: Genta Publishing, 2011), h. viii.

${ }^{4}$ Soerjono Soekanto, Faktor-faktor yang Mempengaruhi Penegakan Hukum, I (Jakarta: Rajawali Pers, 2011), h. 9. 
kepolisian dan kejaksaan. Menurut Soerjono, penegak hukum adalah kalangan yang secara langsung berkecimpung dalam bidang penegakan hukum, yakni yang bertugas di bidang kehakiman, kejaksaan, kepolisian, kepengacaraan dan pemasyarakatan. ${ }^{5}$

Menurut Satjipto Rahardjo, penegakan hukum tak bisa dilepaskan dari peran dan tingkah laku manusia. Hukum tidak bisa tegak dengan sendirinya. Hukum tidak mampu mewujudkan sendiri ide-idenya atau kehendak-kehendaknya yang terdapat dalam peraturan-peraturan hukum. ${ }^{6}$ Makanya dibutuhkan keterlibatan manusia sebagai aparat penegak hukum yang merupakan bagian dari struktur hukum. Jadi jelas bahwa peradilan beserta aparatnya sebagai struktur hukum menjadi bagian penting dari sistem hukum dalam rangka mewujudkan penegakan hukum.

Sedangkan substansi hukum mencakup aturan-aturan hukum, baik yang tertulis seperti undang-undang maupun yang tidak tertulis seperti kebiasaan-kebiasaan yang hidup di masyarakat. Substansi hukum tidak dapat dipisahkan dari struktur hukum karena merupakan patokan atau acuan bagi aparat hukum dalam pelaksanaan hukum. Jadi posisi substansi hukum juga tidak kalah penting dalam penegakan hukum. Sementara kultur hukum adalah sikap manusia terhadap hukum. Meliputi opiniopini, kebiasaan-kebiasaan, cara berpikir dan bertindak, baik penegak hukum maupun masyarakat.

Menurut Soerjono Soekanto, penegakan hukum berasal dari masyarakat dan bertujuan untuk mencapai kedamaian dalam masyarakat. Oleh karena itu, masyarakat memiliki posisi yang penting dalam hukum. Masyarakat dapat mempengaruhi hukum, khususnya penegakan hukum. Sementara itu, masyarakat biasanya terdiri dari orang-orang yang memiliki latar belakang dan pengalaman yang berbeda-beda. Ada yang sendirinya memiliki sikap mentaati hukum, namun ada juga yang pura-pura mentaati, ada juga yang tidak mengacuhkannya sama sekali, bahkan ada pula yang terang-terangan melawan hukum. ${ }^{7}$ Dapat ditegaskan bahwa struktur hukum dan substansi hukum tidak akan dapat mewujudkan

\footnotetext{
${ }^{5}$ Soerjono Soekanto, Faktor-faktor yang Mempengaruhi Penegakan Hukum, h. 19.

${ }^{6}$ Soerjono Soekanto, Faktor-faktor yang Mempengarubi Penegakan Hukum, h. 7.

7 Soerjono Soekanto, Faktor-faktor yang Mempengarubi Penegakan Hukum, h. 45-48.
} 
penegakan hukum sebagaimana yang diidekan bilamana tidak ditunjang oleh budaya hukum yang baik dari masyarakat sebagai sasaran penegakan hukum. Bahkan, unsur struktur dan substansi hukum juga banyak dipengaruhi oleh kultur hukum. Misalnya, aparat hukum harus memiliki kesadaran kultural yang baik pula dan substansi hukum dibentuk dari gagasan-gagasan cerdas yang tak lepas dari pengaruh kultur hukum yang melingkupinya.

\section{Sekilas Islamisasi dan Penegakan Hukum Islam di Kesultanan Buton}

Islam masuk ke Buton sekitar awal abad XV namun secara resmi dianut oleh kerajaan pada sekitar tahun $948 \mathrm{H}$ atau tahun $1540 \mathrm{M}$, setelah Syekh Abdul Wahid dipanggil oleh raja dan bangsawan Buton ke Keraton Buton di Wolio untuk mengajarkan agama Islam sekaligus mengislamkan Sultan dan bangsawan Buton. Ketika itulah sistem Kerajaan Buton berubah menjadi sistem Kesultanan Buton. Masa itu bertepatan dengan masa pemerintahan Raja Lakilaponto yang setelah menganut Islam diberi gelar Sultan Murhum. ${ }^{8}$ Kedatangan Syekh Abdul Wahid dalam mengislamkan Murhum tersebut, menurut leluhur Wolio, merupakan kedatangannya yang kedua. Sebelumnya, pada sekitar tahun $933 \mathrm{H}$ atau 1527 M, Syekh Abdul Wahid telah berkunjung ke Buton melalui kampung Burangasi, kecamatan Sampolawa. ${ }^{9}$ Namun pada kedatangan beliau yang kedua itulah berhasil menunaikan tugas besar dalam mengislamkan Buton yang kelak menjadi salah satu titik peradaban Islam yang dicatat oleh sejarah.

Berbeda dengan sebelumnya, setelah Murhum memeluk Islam, jabatan raja disesuaikan dengan gelar jabatan dalam Islam yakni "Sultan". Hal ini sekaligus menandai berakhirnya masa kerajaan sebelum Islam.

\footnotetext{
${ }^{8}$ Haliadi, Islam Buton dan Buton Islam : Pembauran Adat dan Islam dalam Sejarah Masyarakat Buton, 50. Lihat juga La Niampe, "Unsur Tasawuf dalam Naskah Undang-Undang Buton", Literasi, Vol 1, No 1 (2011), h. 43-58. Usman, "Strategi Buton Menghadapi Ancaman Ternate, Gowa, dan VOC”, Jurnal Masyarakat \& Budaya, Vol 13 No. 1 (2011), h. 185-196. Muhammad Abdullah, "Manuskrip Keagamaan dan Islamisasi di Buton Abad 14-19”, Sari (2007), h. 107-117. Hiroko K. Yamaguchi. "Manuskrip Buton: Keistimewaan dan Nilai Budaya." Sari (ATMA) 25 (2007): h. 41-50.

${ }^{9}$ Abdul Mulku Zahari, Daarul Butunni dan Adatnya (Bau-bau: CV Dia dan Aku, 2017), h. 51 .
} 
Murhum merupakan Raja yang ke-6 dan menjadi sultan yang pertama dengan gelar kesultanan "Sultan Qaimuddin".

Setelah resmi memeluk Islam, Sultanpun mulai menyesuaikan ketentuan-ketentuan kerajaan menurut hukum Islam. Sebelum Islam, falsafah hidup orang Buton dikenal dengan "binci-binciki kuli, poangkaangkataka, molaloko dadi maekaia, ilalomudadi maasia keya", artinya saling cubit-mencubit, saling angkat-mengangkat, yang tua harus ditakuti, dan yang muda harus dikasihani." Falsafah tersebut merupakan mental utama masyarakat Buton sebagai individu maupun secara sosial. Falsafah ini kemudian terinterpretasi menjadi falsafah persatuan dan kesatuan dalam sistem Kerajaan Buton yang berbunyi: bolimo arataa somanamo karo, bolimo karo somanamo lipu, bolimo lipu somanamo adati" yang artinya: janganlah harta asalkan diri, janganlah diri asalkan adat. Setelah masuknya Islam, falsafah tersebut berubah menjadi: bolimo karo somanamo lipu, bolimo lipu soamnamo adati, bolimo adati somanamo agama", yang artinya: janganlah diri asalkan daerah, janganlah daerah asalkan adat, janganlah adat asalkan agama." Maksudnya, bagi orang Buton, agamalah yang dianggap paling mendasar dalam prinsip hidup mereka. ${ }^{10}$ Agama, dalam hal ini Islam, bagi orang Buton ditempatkan dalam posisi tertinggi, melebihi adat, daerah dan diri.

Setelah Buton resmi diislamkan, mulailah Sultan mengadakan penyebaran Islam beserta ajaran-ajarannya yang diawali dari dalam keraton dan kemudian di kampung-kampung di sekitar ibukota hingga meluas sampai pada pedalaman kerajaan. Upaya tersebut dimulai dengan pengajian Alquran yang diawali pada keluarga istana serta pengikutpengikut Murhum serta pejabat-pejabat kerajaan, kalangan bangsawan pada umumnya sehingga terjadi penyebaran pada seluruh rakyat. ${ }^{11}$ Tampak adanya upaya yang cukup strategis sehingga mampu membuahkan

${ }^{10}$ Abdul Mulku Zahari, 50. Terkait falsafah kesultanan Buton bisa dilihat dalam artikel Nanik Hindar Hindaryatiningsih. "Model Proses Pewarisan Nilai-nilai Budaya Lokal dalam Tradisi Masyarakat Buton." Sosiohumaniora 18, no. 2 (2017): h. 100-107. La Niampe. "Pengaruh Islam dalam Kebudayaan Lokal di Button: Satu Kajian Berdasarkan Teks Sarana Wolio." El-Harakah (Terakreditasi) 14, no. 2 (2013): h. 243-267.

${ }^{11}$ Abdul Mulku Zahari, Islam di Buton: Sejarah dan Perkembangannya, Cet I (Bau-Bau: CV Dia dan Aku, 2017), h. 86. 
hasil yang signifikan. Upaya lain yang dilakukan Murhum dalam rangka pelaksanaan hukum Islam di Kesultanan Buton adalah membangun masjid keraton yang bertempat di Kaliwu-liwuto dan menggalakkan aktifitasaktifitas keagamaan seperti pengajian di masjid tersebut. Pelaksanaan pengajian setelah salat berjamaah di masjid merupakan salah satu kebiasaan di Keraton yang juga diteruskan hingga masa Muh. Idrus dengan dilaksanakan di masjid Baadia dan pendopo istana. ${ }^{12}$

Keberhasilan sultan pertama dalam mengislamkan dan menyebarkan ajaran Islam di Kesultanan Buton kemudian dilanjutkan sultan-sutan berikutnya, dan salah satu yang cukup terkenal adalah Sultan Dayanu Ikhsanuddin. ${ }^{13}$ Beliau bahkan berusaha mengadaptasikan ajaran Islam dengan adat sehingga Islam dapat meresap masuk dalam kalangan masyarakat Buton. Pada masa beliaulah, undang-undang kerajaan Buton dibentuk dan diundangkan. Beliau menduduki tahta kesultanan selama 34 tahun dari tahun 1578 sampai tahun $1616 .{ }^{14}$ Dapat dikatakan, masa ini merupakan fase terpenting selain fase Islamisasi dalam rentetan sejarah Kesultanan Buton. ${ }^{15}$ Bagaimana tidak, keberadaan sebuah undang-undang otomatis akan membawa dinamika baru dalam sebuah tata pemerintahan yang berbasis Islam.

Pasa masa Sultan Dayanu Ikhsanuddin, Islam sudah berkembang dengan pesat di Buton dan sudah menyebar masuk ke hampir seluruh wilayah pedalaman. Sultan Dayanu Ikhsanuddin berhasil menyusun undang-undang kerajaan berdasarkan Islam, bersama-sama dengan dua pejabat kerajaan yaitu La Singga dan La Bula. Undang-undang tersebut dikenal dengan nama Istiadatul Azali dan Martabat Tujuh. ${ }^{16}$ Dalam pe-

${ }^{12}$ Abdul Mulku Zahari, Islam di Buton: Sejarah dan Perkembangannya, h. 89-90.

${ }^{13}$ Terkait kepemimpinan Dayanu Ikhsanuddin bisa dilihat dalam karya Riswandha Imawan. "Sistem Pemerintahan Kesultanan Buton pada Masa Kepemimpinan Dayanu Ikhsanuddin." PhD diss., (Yogyakarta: Universitas Gadjah Mada, 2003).

${ }^{14}$ Haliadi, Islam Buton dan Buton Islam: Pembauran Adat dan Islam dalam Sejarah Masyarakat Buton, h. 131.

15 Muhammad Abdullah. "Manuskrip Keagamaan dan Islamisasi di Buton Abad 1419." Sari 25 (2007): h. 107-117. Rosdin, Ali. "Buton, Islamization, and this Manuscript Tradition." International Journal of Nusantara Islam 2, no. 2 (2014): h. 101-116. Muhammad Alifuddin. "Transformasi Islam dalam Sistem Sosial Budaya Orang Buton: Tinjaun Historis." Shautut Tarbiyah 28, no. 1 (2013): h. 1-23.

${ }^{16}$ Terkait Martabat Tujuh sebagai Undang-Undang di Kerajaan Buton bisa dilihat dalam 
nyusunannya, sultan mendapat petunjuk dan nasihat hukum dari Syarif Muhammad, seorang berkebangsaan Arab yang berada di Buton dalam rangka penyiaran Islam. Setelah disusun, diundangkanlah Martabat Tujuh dan Istiadatul Azali, atas nama kerajaan oleh La Singga Sangia iTapi-Tapi, di depan rapat raksasa yang dihadiri oleh seluruh lapisan masyarakat di depan Masjid Agung Keraton.

Pemberlakuan Martabat Tujuh sebagai undang-undang kerajaan semakin memperkokoh posisi syariat Islam sebagai hukum yang harus dipatuhi. ${ }^{17}$ Sejalan dengan itu pula, tempat-tempat peribadatan terus ditingkatkan pembangunannya di samping gedung-gedung pendidikan tidak saja di sekitar keraton tetapi juga di pelosok-pelosok kerajaan. Penyiaran-penyiaran Islam di pedalaman dipelopori oleh kalangan istana serta menteri dan Bobato kerajaan dengan mendapat bantuan sepenuhnya dari pemuka masyarakat setempat. ${ }^{18}$ Keterlibatan serius para elit kesultanan merupakan kunci keberhasilan islamisasi di Buton yang bisa berlangsung dalam waktu yang cukup singkat.

Mengenai pelaksanaan hukum Islam di Kesultanan Buton, menurut al-Mujazi Mulku Zahari, sejak sultan pertama sebagai raja ke-6, sudah mulai dikenal Islam dan hukum Islam telah diterapkan dengan berdasar pada Alquran dan Hadis. Orang yang mencuri dikenai hukuman potong tangan, yang berzina dirajam, dikenakan denda, dimasukkan di dalam alat perangkap ikan baru dibuang di laut. ${ }^{19}$ Penerapan hukuman tersebut merupakan bagian dari upaya pelaksanaan hukum Islam di Kesultanan Buton.

artikel Mahrudin. "Nilai-Nilai Hukum dalam Undang-Undang Murtabat Tujuh Buton." Al-'Adl 8, no. 2 (2015): h. 123-139. La Niampe. "Mysticism Elements In Law Of Buton Manuscript." Literasi: Indonesian Journal of Humanities 1, no. 1 (2011): h. 43-58. Abdul Rahim Yunus. "Nazariyat Martabat Tujuh fi Nizam al-Mamlakah al-Butaniyyah.” Studia Islamika 2, no. 1 (1995). La Niampe. "Sufism Elements Within The Manuscript Of Buton Law." Educationist 184 (2012).

${ }^{17}$ Muhammad Roy Purwanto. "Acculturation among Local Wisdom, Law and Sufism in Forming Martabat Tujuh Enactment of Buton Sultanate." International Journal of Humanities and Management Sciences (IJHMS) 4 (2016).

${ }^{18}$ Haliadi, Islam Buton dan Buton Islam: Pembauran Adat dan Islam dalam Sejarah Masyarakat Buton, h. 142.

${ }^{19}$ Al-Mujazi Mulku Zahari, Tokoh Masyarakat Buton, Wawancara, 1 Mei 2017 di BauBau Sulawesi Tenggara. 
Sebagai wujud keseriusan dalam pelaksanaan hukum Islam pada masa-masa awal, seorang penyiar Islam di Buton yang bernama Syekh Abdul Wahid dalam jabatannya sebagai imam kesultanan sekaligus qadhi, konon sangat ketat menjalankan hukum Islam. Bahkan, Sultan sendiri diminta menjatuhkan talak atas istrinya yang bernama Wa Ode Pogo yang merupakan saudaranya sendiri dan dinikahinya sebelum memeluk Islam. Talak tersebut diperintahkan dengan dasar perkawinan antar saudara bertentangan dengan hukum Islam. Sultan pun melaksanakan perintah untuk menceraikan istrinya meskipun pihak Wa Ode Pogo sangat kecewa dengan keputusan tersebut dan menjadi dendam kepada Syekh Abdul Wahid yang juga merupakan gurunya sendiri. ${ }^{20}$

Kisah di atas menegaskan keseriusan pelaksanaan hukum Islam di Kesultanan Buton, termasuk di masa-masa awal. Berbagai perbuatanperbuatan melanggar hukum, dilaksanakan dengan tidak memandang bulu. Bahkan, seorang pejabat sultan dikenakan hukuman mati, Sultan tersebut adalah Sultan Mardan Ali La Cila, putra almarhum Sultan Dayanu Ikhsanuddin Laelangi. Akibat hukuman tersebut, Sultan La Cila dikenal dengan nama "Gogoli Liwuto" artinya yang diikat lehernya di Pulau Makassar. Sultan dihadapkan di muka sidang negeri kerajaan karena melakukan perbuatan yang amat tercela dalam pandangan agama Islam dan adat negeri. ${ }^{21}$ Pelanggaran ini dinilai aib oleh Sio Limbona. Maka diputuskanlah untuk menghukum mati sultan tersebut dengan terlebih dahulu diturunkan dari jabatannya. Hasil pertemuan di Baruga menyepakati sultan harus dibunuh. ${ }^{22}$

Pelaksanaan hukum yang tanpa pandang buluh juga tampak pada masa Sultan Muh. Idrus yang menjatuhkan hukuman mati kepada pamannya sendiri, saudara sebapak dari ayahnya karena melakukan perbuatan yang amat tercela. Sultan mendapat laporan bahwa pamannya yang bernama Laode Afridi, Lakina Mawasangka, dalam jabatannya sering

${ }^{20}$ Haliadi, Islam Buton dan Buton Islam: Pembauran Adat dan Islam dalam Sejarah Masyarakat Buton, h. 90.

${ }^{21}$ Haliadi, Islam Buton dan Buton Islam: Pembauran Adat dan Islam dalam Sejarah Masyarakat Buton, h. 143.

22 Wawan Erwiansyah, Ketua Umum Media Center Keraton Buton, 31 April 2017 di Bau-Bau Sulawesi Tenggara. 
melakukan kekerasan terhadap rakyat untuk kepentingannya sendiri. Jika rakyat tidak memberikan barang atau uang kepadanya, maka rakyat akan dianiaya atau dihukum menjadi budak. Atas kesalahannya tersebut, La Ode Afridi dijatuhi hukuman mati dengan diikat lehernya dan hukuman dilaksanakan di atas pulau Mbela-mbela kepualauan Tiworo. Pada saat pengambilan keputusan, sebenarnya Syara' kerajaan menentang keputusan sultan tersebut namun sultan bersikukuh dengan alasan bahwa hukum tidak mengenal keluarga sultan. ${ }^{23}$

Realitas ini semakin mempertegas bahwa hukum Islam yang diterapkan di Kesultanan Buton menempatkan masyarakat dalam posisi sama di hadapan hukum. Di samping itu, pelaksanaan kewenangan pemerintah di Kesultanan Buton, termasuk dalam pelaksanaan hukum, selalu ditempuh melalui mekanisme musyawarah. Mekanisme musyawarah merupakan proses penting yang harus dilalui dalam pemutusan hukum dengan mengacu pada aturan-aturan yang mengikatnya.

\section{Pengorganisasian Peradilan di Kesultanan Buton}

Peradilan di Kesultanan Buton tak lepas dari keberadaan aparatur atau pejabat Kesultanan. Mulai dari Sultan bersama-sama perangkat kesultanan lainnya seperti Sapati, Kenepulu, Bonto Ogena, Sabandara, Sio Limbona hingga pejabat keagamaan seperti imam dan khatib, memegang peranan penting dalam penegakan hukum. Kewenangan di bidang peradilan menjadi bagian dari kewenangan mereka sebagai aparat resmi negara.

Pejabat kesultanan seperti Kenepulu memiliki peranan penting dalam peradilan. Kenepulu sebagai sekretaris sultan, bisa juga jadi hakim atau jaksa. Bisa menuntut, bisa juga menjatuhkan hukuman. Kanepulu berwenang dalam perkara terutama yang berkaitan dengan masalah harta pada masyarakat bawah. Sedangkan untuk kalangan pejabat kesultanan adalah Sio Limbona. Jadi, untuk kalangan Sultan, Kanepulu dan Sapati, yang punya kewenangan mengadilinya adalah Sio Limbona.

${ }^{23}$ Haliadi, Islam Buton dan Buton Islam: Pembauran Adat dan Islam dalam Sejarah Masyarakat Buton, h. 199. 
Secara garis besar, pengorganisasian peradilan di Kesultanan Buton terdiri dari Syarana Adati yang menangani masalah-masalah hukum pidana dan perdata dan Syarana Hukumu atau Syarana Agama yang menangani masalah-masalah talak, rujuk, fasakh dan pembagian warisan. Sedangkan masalah-masalah perdata adat di tingkat bawah ditangani oleh Bonto, Bobato, Parabela dan Wati di wilayah Kadie. Adapun personil badan Peradilan Adat (Syarana Adati) terdiri atas: Sultan, Sapati, Kenepulu, Bonto Ogena dan Sio Limbona. ${ }^{24}$

Sedangkan menurut Laode Imran, badan peradilan umum atau lembaga judikatif adalah Sara Hukumu. Lembaga ini merupakan lembaga yang sengaja dibuat untuk peradilan. Di situlah diputuskan berbagai perkara, baik rakyat jelata, pejabat maupun sultan itu sendiri, harus melalui proses di Sara Hukumu. Lembaga ini beranggotakan 9 orang Sio Limbona ditambah 1 orang Lakina Agama dan 1 orang Perdana Menteri atau Sapati. Kadang-kadang dalam Sara Hukumu, Kenepulu juga disertakan. Makanya Kenepulu digelari dengan raja hakim. ${ }^{25}$

Putusan Sara Hukumu terdiri atas:

1. Dosa, membayar utang bagi yang bersalah

2. Pasabu, memecat bagi yang punya jabatan

3. Pomurusi, penyitaan harta kekayaan, mislanya pelaku korupsi yang mengambil uang negara.

4. Papasi, pengasingan, yakni harus keluar dariwilayah Kesultanan Buton

5. Pekamate, hukuman mati.

Pekamate biasanya dijatuhkan pada pelaku makar atau penyalahgunaan wewenang oleh pejabat negara. Misalnya Sultan Buton ke-8 yang dijatuhi hukuman mati karena melakukan perjanjian dengan Belanda tanpa izin dari Dewan Kesultanan dan juga disinyalir telah melakukan pelecehan seksual. ${ }^{26}$

${ }^{24}$ Haliadi, Islam Buton dan Buton Islam: Pembauran Adat dan Islam dalam Sejarah Masyarakat Buton, h. 82.

${ }^{25}$ Laode Imran Kudus, Akademisi dan Pemerhati Budaya Buton, 31 April 2017 di BauBau Sulawesi Tenggara.

${ }^{26}$ Laode Imran Kudus, Akademisi dan Pemerhati Budaya Buton. 
Kalau sultan sendiri yang melanggar hukum, akan dirapatkan oleh Sio Limbona yang akan membicarakan dalam rapat-rapat mereka. Di awal periode banyak sultan yang dimakzulkan. Ada yang hanya 2 tahun, ada yang hanya 7 hari. Semua para pejabat itu akan dikontrol oleh Sio Limbona. Sio Liombona inilah yang memegang adat-istiadat dan peraturan di Kesultanan Buton. Anggotanya harus cerdas, tegas dan cakap dan menguasai aturan-aturan di Kesultanan Buton. Disamping karena keturunannya juga. ${ }^{27}$

Pelaksanaan hukuman terhadap pelanggar hukum dipaparkan oleh Laode Imran sebagai berikut:

Hukuman rajam diberlakukan bagi yang berzina dan sudah berkeluarga. Dieksekusi di depan Masjid Keraton. Digalikan lubang baru pelakunya ditanam sampai leher baru dilempari batu oleh 40 orang mukim. Batunya besar-besar. Hukuman ini hanya berlaku pada laki-laki. Sementara bagi perempuan, cukup ditikam saja. Sedangkan yang mencuri, diberlakukan hukum potong tangan. Jadi waktu penggalian di sekitar benteng keraton, sekitar tahun 80-an, di situ didapatkan kuali besar-besar di bawah tanah. Para arkeolog berusaha mencari tahu tentang hal tersebut dan kebetulan waktu itu masih banyak orang-orang tua, merekalah yang menginformasikan bahwa kuali itu terkait hukuman potongan tangan bagi pencuri di zaman kesultanan. Tangan yang sudah dipotong jari-jarinya dimasukkan dalam kuali yang berisi minyak panas untuk mencegah infeksi, kemudian potongan tangan digantung atau dijejer di atas pinggir benteng keraton sebelah utara. ${ }^{28}$

Pemaparan di atas menjadi indikasi bahwa pada masa Kesultanan hukum Islam benar-benar dilaksanakan di Kesultanan Buton, tidak hanya dalam bidang perdata, tetapi juga dalam perkara pidana, seperti dalam tindak kejahatan pencurian dan zina yang dilarang dalam hukum Islam.

Sedangkan badan Syara Agama atau Syarana Hukumu terdiri atas: Sultan, Lakina Agama, Imam Keraton Buton, 4 orang khatib dan 10 orang Moji/Bilal. Pada masa Sultan Syaiful Anami, yakni sekitar tahun 1922-1924, jumlah Bilal ditambah dari sepuluh orang menjadi dua belas orang yang ditugaskan sebagai pencatat nikah, talak dan rujuk.

\footnotetext{
${ }^{27}$ Laode Imran Kudus, Akademisi dan Pemerhati Budaya Buton.

${ }^{28}$ Laode Imran Kudus, Akademisi dan Pemerhati Budaya Buton.
} 
Seorang Bilal ditempatkan di setiap distrik. ${ }^{29}$ Jadi, jika dirinci, Syarana Hukumu atau Syarana Agama yang berpusat di Masjid Agung Keraton Buton masing-masing terdiri dari satu orang Lakina Agama (Kadhi), satu orang imam, empat orang khatib, 4 orang moji atau bisa dukun, 4 orang moji tungguna aba (penjaga kotak amal), 4 orang moji tungguna bula (ahli hisab) ditambah 40 orang mokimu.

Syarana Hukumu/Agama memiliki posisi yang strategis dikesultanan Buton. Imam merupakan pemimpin dalam struktur Syarana Hukumul Agama sekaligus masuk dalam struktur pemerintahan pusat bersama lakina agama (kadhi). Perangkat ini tidak hanya bertanggung jawab secara normatif dalam hal ini mengurusi masalah hukum agama, halal haram, sunnat, sah batal, makruh dan mubah, namun juga menjadi pemimpin ruhani masyarakat. Oleh karenanya, posisi imam dalam tradisi Buton juga disebut sebagai Sultan Batin. Sedangkan sultan sendiri disebut Sultan Zahir. ${ }^{30}$

Tampak bagaimana pentingnya posisi Imam dalam Kesultanan Buton sebagai pemimpin atau Sultan Batin bagi masyarakat Buton selain sebagai kepala pemerintahan dalam pelaksanaan hukum Islam. Imam juga bertugas memimpin salat di masjid Agung Keraton dan sebagai penghulu dalam masyarakat. Pejabat Imam diangkat dari golongan Kaomu. Sementara Khatib bertugas membaca khutbah di Masjid Agung Keraton Buton dan menjadi juru dakwah Sultan terhadap masyarakat Buton. Khatib juga dapat menggantikan imam bila berhalangan.$^{31}$

Sebagaimana telah disebutkan sebelumnya bahwa Syarana Hukumu atau Syarana Agama menangani masalah-masalah perkara perdata tertentu. Pejabat Syarana Agama adalah orang yang pernah duduk di pemerintahan. Mereka harus menjadi teladan di masyarakat. Lakina Agama sebagai pejabat utama di Syarana Agama boleh dikatakan juga sebagai lembaga Peradilan Agama. Wewenangnya meliputi perkawinan, perceraian dan harta warisan.

29 Haliadi, Islam Buton dan Buton Islam: Pembauran Adat dan Islam dalam Sejarah Masyarakat Buton, h. 117.

${ }^{30}$ M. Alifuddin, Islam Buton: Interaksi Islam dengan Budaya Lokal, Cet I (Jakarta: Badan Litbang dan Diklat Departemen Agama RI, 2007), h. 139.

${ }^{31}$ Haliadi, Islam Buton dan Buton Islam: Pembauran Adat dan Islam dalam Sejarah Masyarakat Buton, h. 81-82. 
Penjabaran tentang Syarana Hukumu atau Syarana Agama dipaparkan Laode Imran Kudus sebagai berikut:

Untuk perkara-perkara tertentu diadili oleh Lakina Agama sebagai qadhi. Jabatan Lakina agama merupakan penyambung antara aparat Masjid Keraton dengan Syarana Hukumu. Pejabat inilah yang menjabarkan persoalan-persoalan hukum Islam. Hukum-hukum fikih mengacu dari fatwa-fatwanya. Pejabat ini berkedudukan di Masjid Agung Keraton sekaligus menjadi perwakilan kesultanan di mesjid, merangkap qadhi. Bidang-bidang pernikahan, talak, cerai dan rujuk menjadi tanggung jawab Lakina Agama. Pejabat Lakina Agama juga harus hadir di Sara Hukumu atau badan peradilan umum, untuk ditanya bagaimana hukum Islam mengenai sesuatu. Ia akan memberikan fatwa dengan mengemukakan beberapa pendapat mazhab. Jadi tidak mudah bagi dia menjadi Lakina Agama. Dia harus bisa menjabarkan hukum Islam walaupun dalam harihari dia kedudukannya di Syarana Agama. ${ }^{32}$

Qadhi atau Lakina Agama menempati posisi penting karena merupakan koordinator yang menghubungkan sultan dengan aparat pejabat Mesjid Agung keraton Buton dalam menjalankan hukum agama. Lakina Agama harus berasal dari golongan Kaomu yang masuk dalam struktur kekuasaan Syarana Wolio sekaligus dalam struktur Syarana Agama (Syarana Hukumu). ${ }^{33}$

Syarana Hukumu merupakan struktur birokrasi penegakan hukum agama yang berpusat di Masjid Agung Keraton Buton. Adapun pembagian kerjanya adalah 4 khatib ditambah 12 orang moji yang mengurus NTCR. Merekalah yang menikahkan seluruh masyarakat Buton. Pejabat Syarana Hukumu juga mengurusi masalah pencatatan perkawinan. Kebetulan pada masa itu, nikah sudah dicatat. Pencatatan meliputi waktu pelaksanaan nikah, identitas mempelai perempuan maupun laki-laki beserta orang tua masing-masing, identitas saksi maupun petugas yang menikahkan. Kemudian mereka bertanda tangan. Sepulang mereka di Keraton, catatan nikah tersebut akan diserahkan kepada imam untuk ditandatangan lagi. Begitu tutup tahun, maka tanda tanganlah sultan di dokumen tersebut. Tidak ada yang boleh

${ }^{32}$ Laode Imran Kudus, Akademisi dan Pemerhati Budaya Buton, wawancara.

${ }^{33}$ Haliadi, Islam Buton dan Buton Islam : Pembauran Adat dan Islam dalam Sejarah Masyarakat Buton, h. 81. 
nikah tanpa pencatatan, untuk menghindari nikah di atas nikah. Jika kedapatan moji menikahkan orang yang masih terikat dengan perkawinan, sang moji akan dipecat karena tidak tertib administrasi. Ketika itu poligami tetap diperbolehkan, namun harus dicatat atau dilaporkan untuk ketertiban. ${ }^{34}$

Tampak bahwa pada masa Kesultanan Buton, pelaksanaan hukum Islam telah dilakukan inisiasi pelaksanaan hukum berupa penertiban administrasi nikah yang meskipun hal tersebut tidak ditegaskan dalam fikih atau hukum Islam perspektif pendapat mazhab. Jadi jauh sebelum lahirnya Undang-Undang Perkawinan apalagi Kompilasi Hukum Islam (KHI), pencatatan nikah telah dikenal, bahkan telah diterapkan di Kesultanan Buton. Bahkan, jauh sebelum kedatangan Belanda di Kesultanan Buton, pernikahan telah dicatatkan untuk mencegah hal-hal yang tidak diinginkan.

Bukan hanya pencatatan, tetapi telah dikenal juga biaya administrasi pencatatan, sebagaimana dijelaskan Laode Imran Kudus:

Setiap yang menikah, ada perongkosan yang harus dibayar. Makanya di kampung-kampung banyak yang nikah massal. Mereka kumpul-kumpul sampai 10 pasangan, kemudian menunggu dari keraton datang untuk menikahkan. Maka setiap satu kali pernikahan, ada namanya Antona $K a b i$, itu yang akan dibayarkan sebanyak 2 boka untuk siapa yang menikahkan. Sebagian uang itu harus disisihkan untuk Lakina Agama. Karena dulu tidak ada sistem gaji. Jadi dari uang itulah dialokasikan untuk orang yang bekerja untuk negara. Kira-kira begitu. Nanti masuk Belanda baru pejabat-pejabat itu digaji. Dulu mereka tidak digaji. Jadi biaya pencatatan sebanyak 2 boka. 2 boka setara dengan 12 C. 1 C sekarang nilai tukarnya senilai dengan 5000. Jadi 12 kali 5000 setara dengan 60.000 Rupiah. Biaya tersebut dialokasikan untuk pejabat yang menikahkan dan Lakina Agama. Termasuk juga bagian untuk Mokimu yang menjadi saksi. Jadi 2 boka itu tinggal bagaimana didistribusikan kepada pihak-pihak yang terkait. ${ }^{35}$

${ }^{34}$ Laode Imran Kudus, Akademisi dan Pemerhati Budaya Buton, wawancara.

${ }^{35}$ Laode Imran Kudus, Akademisi dan Pemerhati Budaya Buton. 
Pada kondisi khusus, perkara perkawinan tertentu diadili langsung oleh Sultan. Misalnya dalam perkara fasakh. Sebagaimana digambarkan Laode Imran Kudus:

Seorang Perempuan yang ditinggalkan lama oleh suaminya kemudian sudah bertahun-tahun minta cerai tapi tidak diceraikan, istilahnya popene, akan datang menghadap meminta keadilan kepada Sultan. Sultan akan memberika putusan, berupa diceraikan. Kaitannya dengan ini, dikenal istilah Adilinas, bahwa semua keputusan sultan dianggap adil. Biasanya laki-laki itu akan dipanggil. Suaminya bisa saja pergi, atau kalau sudah 2 tahun tidak dinafkahi, oleh sultan akan diceraikan. ${ }^{36}$

Kasus-kasus perdata tertentu yang merupakan kewenangan Syarana Hukumu, juga menjadi kewenangan Sultan. Namun dalam sumber lain disebutkan bahwa perempuan atau isteri yang pernikahannya difasakh oleh Sultan akan menjadi budak. Tampaknya ada konsekuensi yang cukup berat bagi seorang isteri yang perkawinannya difasakh langsung oleh Sultan.

Adapun sumber hukum dalam pelaksanaan hukum Islam di Kesultanan Buton dijelaskan oleh Laode Imran sebagai berikut:

Sumber hukum di Kesultanan Buton adalah pertama, Sarana Wolio sebagai UUD, kemudian dibuat tafsir oleh Kiyai Haji Abdul Ganiyu, seorang kanepulu, dalam bahasa Melayu dengan judul Al-Mir'atun Tamam, artinya "Cermin yang Sempurna". Di dalamnya dimuat tentang hukum-hukum yang berlaku di Kesultanan Buton. Dikembangkan lagi menjadi undangundang dengan nama Sarana Barata atau Undang-undang Daerah Otonom. Ada juga Sarana Kompanyia atau Undang-undang Militer, Sarana Bonto Inunca atau Undang-undang tentang Protokoler Istana. Selanjutnya Pada zaman pemerintahan Kesultanan Muhammad Isa, keluar buku Istiadat Negeri Buton, penyempurnaan dari Sarana Wolio yang ditulis dalam Bahasa Melayu. Sekitar Tahun 1854 atau 1855. Khusus untuk nikah, talak, cerai dan rujuk (NTCR), ada kitab khusus yaitu Mahafani, Kitab al-Faraid untuk pembagian hak waris. Kitab lainnya adalah Kitab Istiadatul Azali, tentang bagaimana dasar-dasar Sarana Wolio dibuat, Kitab Al-Majmuah Sio Limbona dan masih ada beberapa lagi. ${ }^{37}$

\footnotetext{
${ }^{36}$ Laode Imran Kudus, Akademisi dan Pemerhati Budaya Buton.

37 Laode Imran Kudus, Akademisi dan Pemerhati Budaya Buton.
} 
Dapat disimpulkan bahwa sumber hukum di Kesultanan Buton adalah: Alquran, Sunnah, Martabat Tujuh, Istiadatul Azali, Mahafani, Faraid dan mitab-kitab lainnya. Sedangkan bentuk-bentuk hukuman di Kesultanan Buton adalah karimbi (denda), pekamate (hukuman mati), andalai kuwiwi, tatalima (potong tangan), kabebe dara (pukulan cambuk atau rajam), buse (pengasingan), dodobiwi (melukai bibirnya) dan kabatua atau kasimbatua (perbudakan). ${ }^{38}$

Adapun masalah-masalah kemasyarakatan yang ditangani oleh Peradilan Islam sampai kepada sultan terakhir adalah:

1. Hubungan keluarga, suami dan anak dalam masalah perkawinan, rujuk, fasakh dan pembagian harta warisan bila tidak ada perdamaian.

2. Pelanggaran larangan agama Islam seperti pencurian, perampokan, perzinaan, pembunuhan, penganiayaan.

3. Kelalaian melaksanakan perintah agama Islam seperti salat dan puasa.

4. Pelanggaran hukum adat atau hukum yang telah ditetapkan sultan dalam hal cara berpakaian yang tidak sesuai dengan tingkatan kedudukan (kaomu, walaka, appara), menentang kebijkasanaan sultan.

5. Sengketa antara satu sama lain mengenai masalah sengketa tanah atau hak milik, sengketa yang tidak dapat didamaikan dari bawah oleh weti, parabela, bonto dan bobato. ${ }^{39}$

Jelaslah bahwa pelaksanaan hukum Islam di Kesultanan Buton melalui peradilan Islam meliputi perkara perdata dan pidana sekaligus. Namun setelah tahun 1906, hukum pidana di Kesultanan Buton didasarkan pada hukum Hindia Belanda. Hukum perdata khususnya di bidang nikah, talak, fasakh, rujuk dan pembagian warisan masih diatur dan diurus kesultanan secara tradisional. Tidak hanya di Buton, kondisi semacam ini tampak pada sebuah wilayah kesultanan yang sempat dimasuki oleh Belanda.

${ }^{38}$ Haliadi, Islam Buton dan Buton Islam: Pembauran Adat dan Islam dalam Sejarah Masyarakat Buton, h. 118.

39 Haliadi, Islam Buton dan Buton Islam: Pembauran Adat dan Islam dalam Sejarah Masyarakat Buton, h. 117-18. 
Peradilan Islam sebagai lembaga yang bertujuan untuk menampakkan hukum agama, atau pelaksanaan hukum-hukum yang telah ditetapkan oleh agama untuk menghukum manusia secara benar dengan berdasarkan pada hukum yang telah diturunkan Allah Swt., tampaknya juga menjadi tujuan dari lembaga hukum di Kesultanan Buton. Fakta-fakta pelaksanaan hukum Islam pada berbagai kasus menjadi bukti upaya penegakan hukum yang didasarkan kepada hukum-hukum yang terdapat dalam Alquran dan al-Sunnah. Hal ini sebagaimana ditegaskan dalam ayat Q.s. al-Māidah (5) ayat 49:

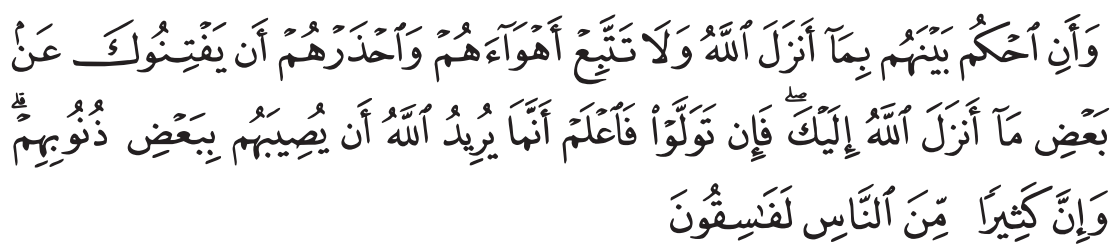

Dan hendaklah kamu memutuskan perkara di antara mereka menurut apa yang diturunkan Allah, dan janganlah kamu mengikuti hawa nafsu mereka. dan berhati-hatilah kamu terhadap mereka, supaya mereka tidak memalingkan kamu dari sebahagian apa yang telah diturunkan Allah kepadamu. jika mereka berpaling (dari hukum yang telah diturunkan Allah), Maka ketahuilah bahwa Sesungguhnya Allah menghendaki akan menimpakan mushibah kepada mereka disebabkan sebahagian dosa-dosa mereka. dan Sesungguhnya kebanyakan manusia adalah orang-orang yang fasik. ${ }^{40}$

Demikian halnya dalam kaitannya dengan asas-asas pokok Peradilan Islam yang meliputi Sumber hukum acara adalah Alquran, al-Sunnah dan Ijma' kaum muslimin, jelas telah diterapkan. Penerapan hukuman potong tangan misalnya, tentunya didasarkan pada Alquran. Kemudian hakim memiliki kemerdekaan dalam memutuskan perkara serta Pihak yang berperkara memiliki kedudukan yang sama serta putusan tidak dapat dibatalkan oleh apapun, jelas telah dilaksanakan. Terbukti dengan adanya raja yang dihukum mati di Kesultanan Buton meskipun tedapat kalangan tertentu yang mencoba mencegah pemberian hukuman tersebut.

${ }^{40}$ Departemen Agama, Al-Qur'an, h. 116. 
Dibandingkan dengan pelaksanaan hukum Islam di kesultanan lainnya di nusantara, seperti di Samudra Pasai, tampak bahwa komitmen pelaksanaan hukum Islam di Kesultanan Buton lebih kuat. Sebagai perbandingan, dalam hikayat Raja-raja Pasai dikisahkan bahwa pernah suatu saat Sultan Ahmad melakukan pelanggaran hukum yang cukup berat yakni membunuh anak laki-lakinya dan memperkosa anak perempuannya, namun ia tidak dihukum mati atas perbuatannya tersebut. ${ }^{41}$ Realitas ini tentunya berbeda dengan di Kesultanan Buton yang berusaha menegakkan hukum Islam tanpa pengecualian, meski terhadap sultan sekalipun.

Mengenai pemisahan kewenangan perkara pidana dan perdata tertentu, sebenarnya bukan tanpa dasar. Strategi atau sistem tersebut dapat dijumpai pada masa-masa sebelumnya, misalnya pada masa khulafaur rasyidin. Seperti telah diuraikan sebelumnya bahwa kewenangan hakim yang diangkat pada masa Khulafaur Rasyidin lebih ditekankan untuk menangani perkara-perkara dalam bidang ahwāl al-syakhshiyyah seperti perkawinan, nafkah dan harta waris. Sedangkan perkara-perkara di bidang jināyah, seperti qisas dan hudûd otoritas penyelesaiannya tetap di tangan khalifah atau gubernur. Demikian halnya kasus yang melibatkan pembesar negara juga diadili oleh khalifah. Jadi boleh dikatakan, hampir mirip dengan pengorganisasian peradilan di Kesultanan Buton.

\section{Peran Peradilan dalam Penegakan Hukum Islam di Kesultanan Buton}

Meskipun telah ditegaskan bahwa sistem Peradilan di Kesultanan Buton merupakan sistem Peradilan Islam, namun menarik untuk ditinjau peran Peradilan Islam tersebut dalam peengakan hukum Islam di Kesultanan Buton melalui kerangka teori sistem hukum.

Sebagaiamana telah dipaparkan sebelumnya bahwa sistem hukum menurut Lawrence M. Friedman meliputi 3 (tiga) unsur penting yakni struktur hukum, substansi hukum dan budaya hukum. Demikian juga, penegakan hukum menurut Surjono Sukanto meliputi 5 (lima) aspek pokok atau dipengaruhi factor-faktor penting yaitu faktor hukumnya,

${ }^{41}$ Lihat Ayang Utriza Yakin, Sejarah Hukum Islam Nusantara Abad XIV-XIX, Cet I (Jakarta: Kencana, 2016), h. 28. 
faktor penegak hukumnya, faktor sarana atau fasilitas, faktor masyarakat dan faktor kebudayaan. Bahwasanya jika unsur-unsur tersebut di atas bisa berjalan dengan baik, maka barulah penegakan hukum dapat terlaksana. Oleh karena itu, akan dicermati pelaksanaan hukum di Kesultanan Buton dengan mengacu pada aspek-aspek penting yang menjadi bagian dari sistem hukum tersebut sebagai standard untuk melihat bagaimana peran peradilan di Kesultanan Buton dalam rangka penegakan hukum Islam di wilayah tersebut sebagaimana akan diurai satu persatu di bawah ini.

Pertama, analisis struktur hukum, yang meliputi institusi dan aparatnya. Seperti telah diuraikan, di Kesultanan Buton terdapat institusi peradilan yang terdiri dari Syarana Adati dan Syarana Hukumu. Syarana Adati untuk kasus-kasus dalam perkara pidana maupun perdata tertentu. Sedangkan Syarana Hukumu/Agama untuk perkara-perkara perdata tertentu yang meliputi perkawinan dan kewarisan. Lembaga ini juga dilengkapi dengan aparat-aparat khusus. Meskipun tampak terjadi pemisahan, namun intinya tetap peradilan Islam karena proses hukum dalam Syarana Adati juga selalu selalu menghadirkan Lakina Agama untuk memberikan fatwafatwa atau pandangan-pandangan berdasarkan hukum Islam. Apalagi didukung dengan fakta-fakta bahwa bentuk-bentuk hukuman pidana yang dijatuhkan di kesultanan Buton adalah hukum Islam seperti hukuman rajam bagi pezina dan potong tangan bagi pencuri. Maka jelaslah bahwa yang diterapkan adalah sistem hukum Islam.

Aparat-aparat hukum di Kesultanan Buton juga boleh dikata memiliki kualifikasi yang cukup baik karena dipilih dari orang-orang tertentu, bahkan dari golongan-golongan tertentu. Mereka digambarkan sebagai pribadi-pribadi yang kuat dan tegas dalam tugasnya, terbukti mampu dibentuk penerapan hukum yang tanpa pandang buluh, meski sultan sekalipun.

Kedua, analisis substansi hukum. Dalam ulasan sebelumnya tampak bahwa di Kesultanan Buton, pelaksanaan hukum didasarkan pada sumbersumber hukum yang jelas, mulai dari Alquran, Sunnah, Martabat Tujuh, Istiadatul Azali, Mahafani, Faraid dan berbagai kitab-kitab lainnya. Martabat Tujuh sebagai Undang-Undang Dasar yang menjadi dasar dalam menjalankan pemerintahan bagi Sultan dan seluruh pejabat di Kesultanan 
Buton tidak diragukan lagi sebagai representasi dari ajaran Islam karena diintrodusir dari Sifat Dua Puluh. Demikian halnya dengan kitab-kitab lainnya yang mengandung hukum Islam. Hal inipun dapat diperkuat dengan fakta pelaksanaan hukum Islam termasuk dalam bidang hukum pidana, sebagaimana digambarkan di atas.

Ketiga, analisis kultur hukum. Pelaksanaan hukum Islam di Kesultanan Buton tak lepas dari dukungan masyarakat Buton sebagai penganut Islam yang taat. Apalagi Islam telah berinteraksi bahkan menyatu dengan baik dalam budaya keseharian masyarakat Buton sehingga lahir istilah Buton adalah Islam, Islam adalah Buton. Sebagaimana ditegaskan M. Alifuddin, seluruh masyarakat etnik Buton adalah beragama Islam. Keyakinan terhadap Islam merupakan bagian yang menyatu dengan kehidupan dan kepercayaan seluruh orang Buton. Keyakinan terhadap Islam menjadi bagian dari darah daging orang Buton. ${ }^{42}$ Kuatnya dasar keyakinan masyarakat Buton terhadap Islam tersebut otomatis akan berpengaruh kuat terhadap ketaatan mereka terhadap ajaran Islam, khususnya hukum Islam. Makanya tak heran jika kemudian sejarah mencatat Kesultanan Buton sebagai salah satu kesultanan di bumi nusantara yang pernah menerapkan hukum Islam secara keseluruhan, termasuk dalam bidang hukum pidana.

Pelaksanaan hukum Islam di Kesultanan Buton telah memenuhi standard teori sistem hukum sebagaimana digagas oleh Lawrence M. Friedman, baik dari sisi struktur hukum, substansi hukum maupun kultur hukum serta penjabaran teori penegakan hukum menurut Soerjono Soekanto. Maka dapat ditegaskan bahwa keberadaan peradilan Islam di Kesultanan Buton memiliki peran yang cukup signifikan dalam mengawal penegakan hukum Islam di Kesultanan Buton. Apalagi jika dicermati kewenangan lembaga Syarana Hukumu yang bertanggung jawab dalam persoalan Agama Islam. Seperti telah dijelaskan bahwa lembaga ini memiliki kewenangan yang sangat luas, lebih luas daripada kewenangan Peradilan Agama yang ada saat ini. Intinya, semua yang menyangkut agama Islam, tidak hanya yang berkaitan dengan nikah, talak dan cerai, tetapi juga

${ }^{42}$ Lihat M. Alifuddin, Islam Buton: Interaksi Islam dengan Budaya Lokal, Cet I, h. 169-70. 
penyelenggaraan perkawinan, pencatatan nikah, hisab dan rukyah dan lainlain. Bila dibandingkan dengan sekarang, tugas Syarana Hukumu seolah menggabungkan antara tugas Peradilan Agama dan Departemen Agama. Maka dapat ditegaskan bahwa lembaga ini memiliki peranan yang sangat menentukan dalam penegakan hukum Islam di Kesultanan Buton.

Meskipun demikian, di lain sisi, kalau dicermati, masih ada celahcelah yang patut dikritisi dalam konteks pelaksanaan hukum Islam di Kesultanan Buton. Misalnya dalam bentuk-bentuk hukuman, terdapat jenis-jenis hukuman yang boleh dikatakan tidak bersumber pada hukum pidana Islam, misalnya hukuman ditikam bagi pezina perempuan atau dimasukkan dalam perangkap ikan baru dibuang ke laut bagi pezina. Bentuk-bentuk hukuman semacam ini patut dipertanyakan sumbernya yang boleh jadi di dalamnya masih ada pengaruh kuat dari hukum adat. Masalah lainnya adalah hukuman dijadikan budak istana bagi isteri yang pernikahannya difasakh oleh raja, tampak bertentangan dengan semangat humanisme yang diusung oleh hukum Islam. Bahkan, bila ditelaah secara mendalam, Islam justeru memiliki semangat mengikis perbudakan. Terbukti beberapa hukuman dalam hukum Islam justru memerdekakan budak, misalnya dalam hukuman kaffarah. Tetapi di Buton, kehadiran Islam di tanah tersebut tampak tidak mampu menghilangkan stratifikasi sosial yang membagi masyarakat dalam 4 (empat) golongan (Kaomu, Walaka, Papara dan Batua), bahkan sepertinya melanggengkan perbudakan yang sebenarnya hendak dihapus oleh Islam.

\section{Penutup}

Kesimpulan dalam tulisan ini menunjukkan bahwa Kesultanan Buton sejak awal setelah Islamisasi langsung melakukan penerapan hukum Islam. Institusi keislaman pun dibentuk, termasuk lembaga hukum Islam berupa peradilan yang disesuaikan dengan hukum Islam. Pengorganisasian peradilan di Kesultanan Buton terdiri dari Syarana Adati yang berwenang dalam perkara pidana dan Syarana Hukumu atau Syarana Agama yang berwenang dalam perkara perdata tertentu seperti perkawinan, perceraian dan kewarisan. Meski terjadi pemisahan kewenangan, keduanya dapat dikategorikan sebagai Peradilan Islam karena hukum yang dijalankan 
didasarkan pada hukum Islam.

Peradilan di Kesultanan Buton merupakan representasi dari Peradilan Islam karena memenuhi unsur-unsur Peradilan Islam dan lembaga tersebut menjadi bagian penting dalam penegakan hukum Islam di Kesultanan Buton. Peradilan Islam di Kesultanan Buton juga telah ditopang oleh struktur, substansi hukum maupun kultur hukum yang kuat baik di kalangan penegak hukum maupun di masyarakat sehingga memiliki peran yang cukup signifikan dalam penegakan hukum Islam di Kesultanan Buton.

Sebagai implikasi dalam tulisan ini, perlunya pewarisan nilai-nilai maupun semangat penegakan hukum Islam di masa kesultanan pada masyarakat kontemporer. Perlunya penelusuran lebih mendalam oleh para peneliti atau ilmuan dalam rangka mendapatkan informasinya yang lebih lengkap lagi tentang sistem penerapan hukum Islam di Kesultanan Buton. Perlunya perhatian tersendiri baik dari pihak pemerintah, lembaga terkait maupun masyarakat luas dalam rangka pelestarian situs-situs bersejarah peninggalan Kesultanan Buton.

\section{Pustaka Acuan}

Abdullah, Muhammad. "Manuskrip Keagamaan dan Islamisasi di Buton Abad 14-19." Sari 25 (2007): 107-117.

Alifuddin, M. Islam Buton: Interaksi Islam dengan Budaya Lokal. Cet I. Jakarta: Badan Litbang dan Diklat Departemen Agama RI, 2007. , "Transformasi Islam dalam Sistem Sosial Budaya Orang Buton: Tinjauan Historis." Shautut Tarbiyah 28, no. 1 (2013): 1-23.

Rosdin, Ali. "Buton, Islamization, and this Manuscript Tradition." International Journal of Nusantara Islam 2, no. 2 (2014): 101-116.

Haliadi. Islam Buton dan Buton Islam: Pembauran Adat dan Islam dalam Sejarah Masyarakat Buton. Yogyakarta: Bidang Pengkajian dan Penerbitan Kemawy, 2001.

Hindaryatiningsih, Nanik Hindar. "Model Proses Pewarisan Nilai-nilai Budaya Lokal dalam Tradisi Masyarakat Buton.” Sosiohumaniora 18, no. 2 (2017): 100-107. 
Imawan, Riswandha. "Sistem Pemerintahan Kesultanan Buton pada Masa Kepemimpinan Dayanu Ikhsanuddin.” PhD diss., Yogyakarta: Universitas Gadjah Mada, 2003.

Mahrudin. "Nilai-Nilai Hukum dalam Undang-Undang Murtabat Tujuh Buton." Al-'Adl 8, no. 2 (2015): 123-139.

Niampe, La. "Mysticism Elements In Law Of Buton Manuscript." Literasi: Indonesian Journal of Humanities 1, no. 1 (2011): 43-58.

, "Unsur Tasawuf dalam Naskah Undang-Undang Buton." Literasi, Vol 1, No 1 (2011): 43-58.

, "Pengaruh Islam dalam Kebudayaan Lokal di Button: Satu Kajian Berdasarkan Teks Sarana Wolio.” El-Harakah (Terakreditasi) 14, no. 2 (2013): 243-267.

, "Sufism Elements Within The Manuscript Of Buton Law.” Educationist 184 (2012).

Purwanto, Muhammad Roy. "Acculturation among Local Wisdom,

Law and Sufism in Forming Martabat Tujuh Enactment of Buton

Sultanate." International Journal of Humanities and Management Sciences (IJHMS) 4 (2016).

Rahardjo, Satjipto. Penegakan Hukum: Suatu Tinjauan Sosiologis. Yogyakarta: Genta Publishing, 2011.

Soekanto, Soerjono. Faktor-faktor yang Mempengaruhi Penegakan Hukum, I. Jakarta: Rajawali Pers, 2011.

Usman. "Strategi Buton Menghadapi Ancaman Ternate, Gowa, dan VOC." Jurnal Masyarakat \& Budaya, Vol 13 No. 1 (2011): 185-196.

Yamaguchi, Hiroko K. "Manuskrip Buton: Keistimewaan dan Nilai Budaya." Sari (ATMA) 25 (2007): 41-50.

Yakin, Ayang Utriza. Sejarah Hukum Islam Nusantara Abad XIV-XIX, Cet I. Jakarta: Kencana, 2016.

Yunus, Abdul Rahim. "Nazariyat Martabat Tujuh fi Nizam al-Mamlakah al-Butaniyyah.” Studia Islamika 2, no. 1 (1995).

Zahari, Abdul Mulku. Daarul Butuuni dan Adatnya. Bau-bau: CV Dia dan Aku, 2017.

Islam di Buton: Sejarah dan Perkembangannya, Cet I. Bau-Bau:

CV Dia dan Aku, 2017. 


\section{Sumber Wawancara}

Al-Mujazi Mulku Zahari, Tokoh Masyarakat Bau-bau, Wawancara Tanggal di Bau-Bau Sulawesi Tenggara. Wawancara Tanggal 1 Mei 2017 di Baubau.

Laode Imran Kudus, Dosen Universitas Muhammadiyah Buton/Turunan Pejabat Kesultanan Buton, Wawancara Tanggal 31 April 2017 di Baubau Sulawesi Tenggara.

Wawan Erwiansyah, Ketua Umum Media Center Keraton Buton, Wawancara Tanggal 31 April 2017 di Baubau Sulawesi Tenggara. 